\title{
SUMMARY
}

Bochkov Pavio. The use of simulators to form postural mechanisms during equilibrium disbalance of preschoolers.

The article explores the possibilities of using material and technical means for overcoming children's imbalances. Literature review on this problem is made, the problems are identified, which have not yet been sufficiently studied.

Particular attention was paid to development and use of authoring simulators for physical education of junior age children with postural deficiency syndrome.

Such simulator constructions as "Restless Pyramid", "Airship", "Cable Car" were considered and characterized. For each simulator were provided its technical characteristics, advice on their manufacture and operation.

Separately for each simulator, its methodological capabilities for overcoming children imbalance in the form of specific complexes of corrective exercises are given.

Each simulator was analyzed from the perspective of its use in five directions, corresponding to the presence of inputs (channels) in the child according to the general postural system of maintaining equilibrium (vestibular, visual, oculomotor, proprioceptive and gift).

M ethodological tips are given for ensuring both the general safety system of children during exercise in physical education classes and specific recommendations for the safe operation of each simulator.

It is proved that simulators are most effective of their together usage with the surrounding 3D correction space. Particular attention was paid to the author's threecomponent and three-level simulator "Restless Pyramid", which allows the child to train the function of dynamic stability in all three planes: frontal, sagittal and horizontal.

With the help of these three simulators, it is possible to effectively form a child's static balance (in place), semi-dynamic balance (moving in place) and dynamic balance (in motion with movement).

Key words simulators, imbalance, junior age children, postural aplomb system.

удК 378.147:811.111

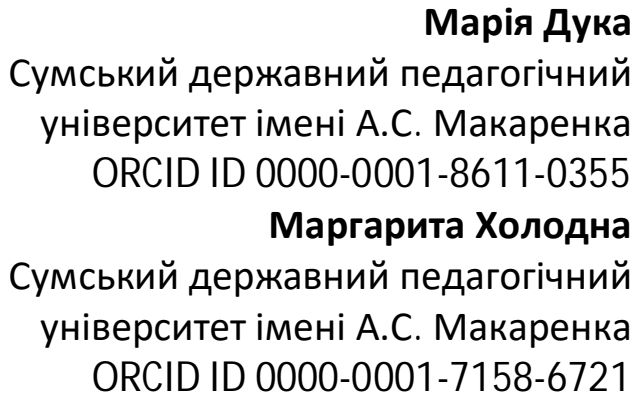

DOI 10.24139/2312-5993/2020.02/348-361

\section{ОСОБЛИВОСТІ ФОРМУВАННЯ АНГЛОМОВНОЇ СОЦІАЛЬНОЇ КОМПЕТЕНТНОСТІ У ПРОЦЕСІ НАВЧАННЯ ДІАЛОГІЧНОГО МОВЛЕННЯ В УЧНІВ 6-ГО КЛАСУ ЗАКЛАДІВ ЗАГАЛЬНОЇ СЕРЕДНЬОЇ ОСВІТИ}

у статті висвітлено низку теоретичних положень щодо особливостей формування англомовної соціальної компетентності у процесі навчання діалогічного мовлення учнів 6-го класу закладів загальної середньої освіти. Систематизовано підходи до визначення поняття «англомовна сочіальна компетентність» та проаналізовано ії специфрічні складники: знання правил вербального й невербального спілкування, мовного етикету, табу, ритуалів, звичаїв та вміння такими знаннями користуватися на практиці. Уточнено складники компетентності в діалогічному мовленні. Узагальнено 
вимоги до формування англомовної сочіальної компетентності у прочесі навчання діалогічного мовлення представлені в чинній шкільній програмі МОН для учнів 6-го класу закладів середньої загальної освіти. Доведено методичну дочільність інтегрованого формування в учнів 6-го класу закладів загальної середньої освіти сочіальної компетентності та компетентності в діалогічному мовленні.

Ключові слова: діалогічне мовлення, соціальна компетентність, лінгвосоціокультурна компетентність, заклад загальної середньої освіти, невербальні засоби комунікації.

Постановка проблеми. На даний момент оволодіння учнями у процесі навчання іноземних мов базовими знаннями, формування в них навичок та розвиток відповідних умінь в області лексики, граматики й фонетики $€$ абсолютно недостатнім для формування іншомовної комунікативної компетентності (ІКК). ІКК є комплексним утворенням, яке у своєму складі налічує певну кількість (суб)компетентностей. Розвиток окремої (суб)компетентності - мовної (лексичної, граматичної, фонетичної) або мовленнєвої (у читанні, аудіюванні, письмі або говорінні) чи певний акцент на будь-якій із них, не дозволяє досягти позитивних результатів, і, як правило, не позбавляє учнів бар'єрів, що стоять на перешкоді вільного спілкування та налагодження діалогу культур.

Відомо, що найчастіше страх спілкування виникає не тільки через недостатню кількість знань лінгвістичного характеру або відсутності практики спілкування, а здебільшого через незнання правил вербального й невербального спілкування: мовного етикету, правил і норм поведінки, табу, ритуалів, звичаїв тощо - аспектів, що входять до складу лінгвосоціокультурної компетентності (ЛСКК) як невід'ємної складової ІКК (Методика навчання іноземних мов і культур, 2013, с. 425-430).

У цьому контексті С. Тер-Мінасова (Тер-Мінасова, 2008, с. 8-10) вважає, що для забезпечення ефективного спілкування між представниками різних культур недостатньо подолати лише мовний бар'єр, адже задля цього потрібно також подолати бар'єр культурний. Вона наголошує на тому, що культурні помилки, які супроводжують і провокують конфлікти культур, сприймаються болючіше й викликають більш негативну реакцію, ніж мовленнєві помилки (Тер-Мінасова, 2008, с. 68). Учена зауважує, що спілкування складається лише з $7 \%$ - власне вербальних засобів, тоді як 38 \% - припадає на фонетичне оформлення мовлення (інтонацію, тон, тембр, теми - поняття так званого надсегментного рівня), а 55 \% інформації передають невербальні засоби комунікації (НЗК) (міміка, жести, рухи тіла, очі, посмішка тощо) (Тер-Мінасова, 2008, с. 95).

Аналіз актуальних досліджень. Проблема формування ЛСКК була проаналізована у працях таких філологів, методистів та педагогів, як Н. Бориско, Є. Верещагін, І. Горєлов, М. Дука, Г. Колшанський, В. Костомаров, Г. Крейдлін, С. Ніколаєва, Л. Рудакова, Л. Солощук, С. Тер-Мінасова, F. Payatos, M. Argyle, J. Hall, B. Korte, D. M atsumoto. 
Метою даної публікації $є$ аналіз теоретичних передумов формування англомовної соціальної компетентності (СК) як складової ЛСКК у процесі навчання діалогічного мовлення та визначення вимог щодо інтегрованого формування цих компетентностей в учнів 6-го класу закладів загальної середньої освіти.

Досягнення поставленої мети передбачало використання таких методів дослідження, як: аналіз, синтез, абстрагування й узагальнення, що надало можливість довести передумови формування англомовної соціальної компетентності у процесі навчання діалогічного мовлення учнів 6-го класу закладів загальної середньої освіти.

Виклад основного матеріалу. Висвітлюючи аспекти, що стосуються формування СК, уточнімо спочатку зміст та структуру ЛСКК, до складу якої вона і входить.

Висвітлюючи досліджуваний феномен, київська методична школа (Методика навчання іноземних мов і культур, 2013, с. 425-432) визначає лСКК як складне і багатокомпонентне утворення, до складу якого входять такі компоненти-(суб)компетентності, як: соціолінгвістична, соціокультурна та соціальна компетентності, кожну з яких розглядають як сукупність певних знань, навичок і вмінь, а індикатором її сформованості є здатність й готовність індивіда до повноцінної участі в процесі міжкультурної комунікації. При цьому, науковці зауважують, що ЛСКК має успішно функціонувати як у безпосередньому, так і в опосередкованому іншомовному міжкультурному спілкуванні та забезпечувати взаєморозуміння партнерів як представників різних культурних спільнот (Методика навчання іноземних мов і культур, 2013, с. 425).

Як бачимо, до складу ЛСКК, окрім уже зазначеної СК, що $є$ у фокусі нашого дослідження, також входять соціокультурна та соціолінгвістична компетентності, проте їх характеристика - не $€$ метою та завданням даної статті. Отже, зупинимося детальніше на розгляді змісту та структури СК.

За словником методичних термінів (Азимов, 2009, с. 286) СК трактується як здатність особистості вступати в спілкування з іншими людьми. Бажання вступати в комунікацію обумовлене наявністю потреби у спілкуванні, мотивів та певного відношення до партнера по спілкуванню та самооцінкою. Уміння вступати в комунікативні відносини вимагає від партнера здатності орієнтуватися в соціальній ситуації та управляти нею.

На думку Л. Панової, І. Андрійко, С. Тезікової (Методика навчання іноземних мов у загальноосвітніх навчальних закладах, 2010, с. 328), СК означає компетентність, що включає знання про соціальні звичаї, умови життя, особливості міжособистісних стосунків, цінності певної суспільної групи.

Представники київської методичної школи (Методика навчання іноземних мов і культур, 2013, с. 430) зауважують, що СК є здібністю особистості вступати в комунікативні стосунки з представниками інших країн 
у певних ситуаціях (орієнтування в цих ситуаціях, керування ними, вирішуючи можливі непорозуміння). СК базується на знаннях певних правил і норм спілкування, ритуалів та моделей комунікативної поведінки, на вміннях їх адекватно інтерпретувати, а також на готовності та бажанні взаємодіяти 3 іншими і на здатності до емпатії, толерантності та неупередженості.

Останнє визначення видається нам найбільш вичерпним, тому будемо ним послуговуватись для надання характеристики кожного 3 компонентів СК.

Серед знань та вмінь, що входять до складу цієї компетентності, знаходять своє місце: 1) знання культурно-специфічних правил і норм спілкування та вміння ними користуватися в різних комунікативних ситуаціях; 2) знання ритуалів і стандартизованих моделей комунікативної поведінки та вміння ними користуватися; 3) знання НЗК, які $\epsilon$ також культурно обумовленими та вміння їх використовувати.

3 метою уточнення вищенаведених компонентів СК пропонуємо розглянути специфіку найбільш складних із них, таких, що викликають найбільшу кількість складнощів під час спілкування.

Зауважимо, що особливу проблему становить такий тип знань культурно-специфічних правил і норм спілкування, як табу, притаманний конкретній лінгвокультурі. У дослідженнях комунікативного етикету табу розглядається як 1) вимога необхідного збереження конфіденційності стосовно особи адресата; 2) завдання не нанести моральної шкоди іншій людині (не обов'язково учаснику даної ситуації спілкування); 3) пересторога стримувати негативні емоції, пом'якшувати або вуалювати негативну інформацію; 4) заборона приниження або образи людської гідності, виключати грубість і насильство (Колтунова, 2005, с. 79).

P. Вордхо (Wardhaugh, 2006, с. 239) виділяє такі теми-табу для англійців, як: смерть, секс, обговорення фізіологічних процесів життєдіяльності людини, релігія, політика.

М. Тульнова (Тульнова, 2010, с. 176-180) також зауважує, що в англійців не прийнято розмовляти про інтимні проблеми, хвороби, релігійні та політичні погляди, теми расової, статевої, національної або етнічної приналежності; виключено питання про доходи (всі фінансові питання краще вирішувати письмово: через листування, але ні в якому разі не наживо), не обговорюються вікові та фізичні характеристики індивіда.

Таким чином, найбільш поширеними тематичними табу, що обмежують теми у спілкуванні в англійській лінгвокультурі, $є$ такі, як: 1) смерть; 2) інтимні стосунки; 3) расова, національна, гендерна, релігійна приналежність; 4) захворювання; 5) дискусійні теми з точки зору моралі, етики і права (аборт, сурогатне материнство, клонування, суїцид тощо); 6) питання особистісного характеру (вік, дохід, місце роботи, сімейний стан тощо). 
Наступною проблемою можуть стати норми поведінки англійського соціуму, тобто правила, дотримання яких забезпечує певну очікувану поведінку, що можуть носити як формальний (норми, зафіксовані в організаційних документах), так і неформальний (норми, що склалися в організації, але не мають документального закріплення) характер.

Відомо, що англійська поведінка - це уособлення всього строгого та офіційного. Саме у Великій Британії зародилося поняття про закони та правила етикету, а англійці вважають себе «справжніми леді й джентльменами», які цінують звичаї, традиції та дотримуються певних норм поведінки.

Так, наприклад, непристойним вважається звертання до незнайомої людини, якщо в першу чергу ви їй не представились. Крім того, англійці уникають відкритого погляду в очі. Варто зауважити, що надмірна емоційність $€$ поганим аспектом у спілкуванні, також потрібно відмовитися від жорсткого та різкого тону. Проте гумор $€$ важливим в англійській культурі. Той, хто знає багато анекдотів, вважається талановитою людиною і така атмосфера буде сприяти успішності переговорів.

Англійці вміють терпляче вислуховувати співрозмовника (проте це не завжди означає згоду). При веденні переговорів іноді виникають паузи, під час яких не потрібно боятися мовчати, навпаки, грубою поведінкою вважається, коли багато говорять, тобто, як вважають англійці, силою нав'язують себе іншим.

Отже, етикет у Великий Британії має свої особливості, зумовлені принципами, нормами, правилами, звичаями, традиціями, що повинні базуватися на правильній поведінці в суспільстві країни та обов'язковому дотриманню цих аспектів, що характерні саме для їхніх універсальних та ідіоетнічних особливостей.

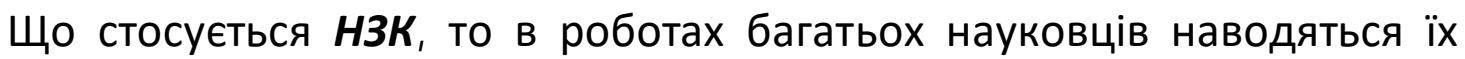
різні визначення (й навіть різні терміни на позначення самого поняття) та їх різні типи.

Узагальнюючи інформацію, що стосується НЗК у дослідженнях I. Горєлова, Г. Крейдліна, Л. Солощук та F.Payatos, у своїй дисертації М. Дука наводить методичну типологію НЗК (табл. 1) (Дука, 2015, с. 38).

Розглянемо далі вимоги навчальної програми, що надає нам змогу проаналізувати сучасний стан речей, що стосується формування ЛСКК та СК як її субкомпетентності в закладах загальної середньої освіти.

Зауважимо, що сьогодні головною метою навчання іноземних мов в основній школі, відповідно до Навчальної програми з іноземних мов закладів загальної середньої освіти для учнів 5-9 класів (Навчальні програми з іноземних мов для загальноосвітніх навчальних закладів і спеціалізованих шкіл із поглибленим вивченням іноземних мов 5 -9 класи, 2017, с. 16-18), є формування в учнів ІКК, що забезпечується лінгвістичним, 
мовленнєвим і соціокультурним досвідом; всебічний розвиток та виховання особистості через формування вмінь та навичок спілкуватися в усній та письмовій формі з урахуванням мотивів, цілей та соціальних норм мовленнєвої поведінки у типових сферах та ситуаціях спілкування. Як бачимо, у Навчальній програмі підкреслюється роль ЛСКК.

Табличя 1

Методична типологія невербальних засобів комунікації

\begin{tabular}{|c|c|c|}
\hline \begin{tabular}{l}
\multicolumn{1}{c}{ Критерії } \\
1. Відповідно до \\
фізичної \\
природи \\
продукування
\end{tabular} & \multicolumn{2}{|r|}{ Типи НЗК } \\
\hline \multirow{4}{*}{$\begin{array}{l}\text { 1. Відповідно до } \\
\text { фізичної } \\
\text { природи } \\
\text { продукування }\end{array}$} & 1. Кінесичні & $\begin{array}{l}\text { Жести, міміка, міреми, пантоміміка (пози, рухи } \\
\text { тіла, манери, особливості статури, ходи) } \\
\text { тактильні рухи }\end{array}$ \\
\hline & 2. Проксемічні & $\begin{array}{l}\text { Зміни особистого простору, дистанції; інтенсив- } \\
\text { ність змін простору; масштаб змін простору }\end{array}$ \\
\hline & 3. Просодичні & $\begin{array}{l}\text { Тембр голосу, темп, голосність, особливості } \\
\text { вимови, паузація або ситуативне мовчання }\end{array}$ \\
\hline & $\begin{array}{l}\text { 4. Знакові } \\
\text { декоративні } \\
\text { елементи }\end{array}$ & $\begin{array}{l}\text { Одяг, стиль зачіски, аксесуари, прикраси, } \\
\text { косметика, } \\
\text { характеристики }\end{array}$ \\
\hline \multirow[t]{3}{*}{$\begin{array}{l}\text { 2. Відповідно до } \\
\text { специфічності } \\
\text { значення }\end{array}$} & 1. Універсальні & $\begin{array}{l}\text { Типові загальнолюдські жести, міміка, рухи тіла, } \\
\text { знакові декоративні елементи, ольфакторні } \\
\text { особливості тощо }\end{array}$ \\
\hline & $\begin{array}{l}\text { 2. Національно- } \\
\text { специфічні }\end{array}$ & $\begin{array}{l}\text { Тобто такі, що є культурно-традиційними для } \\
\text { кожного конкретного суспільства }\end{array}$ \\
\hline & $\begin{array}{l}\text { 3. Індивідуально } \\
\text { визначені }\end{array}$ & $\begin{array}{l}\text { Адекватне розуміння яких потребує додаткових } \\
\text { детальних знань як про біографію автора АХТ, } \\
\text { так і про його наміри стосовно використання } \\
\text { того чи іншого виду НЗК у конкретному } \\
\text { контексті. НЗК, репрезентовані у цій групі, є або } \\
\text { абсолютно новими, вигаданими автором твору, } \\
\text { або дещо зміненими варіаціями національно- } \\
\text { специфічних НЗК }\end{array}$ \\
\hline \multirow{2}{*}{$\begin{array}{l}\text { 3. Відповідно до } \\
\text { контекстуаль- } \\
\text { ного значення }\end{array}$} & 1. Стандартні & $\begin{array}{l}\text { Актуалізують такий поведінковий тип, який } \epsilon \\
\text { значущим у будь-якій ситуації }\end{array}$ \\
\hline & 2. Ситуативні & $\begin{array}{l}\text { Реалізують свою комунікативну настанову лише } \\
\text { за умови їх осмислення в певному контексті }\end{array}$ \\
\hline
\end{tabular}

Згідно з «Загальноєвропейськими рекомендаціями з мовної освіти: вивчення, викладання, оцінювання» (Загальноєвропейські рекомендації з мовної освіти, 2003, с. 219-220), рівень володіння іноземною мовою на кінець 6 класу згідно чинної програми має відповідати рівню А2 (рівень елементарного користувача). Тобто на кінець 6-го класу учень може:

1) розуміти речення повсякденного вжитку;

2) уміти обирати належні конструкції для спілкування в рутинних ситуаціях;

3) уміти описувати ситуацію та знаходити відповіді на елементарні питання. 
Відповідно до зазначеного рівня володіння іноземною мовою, за роки навчання в основній школі учні мають набути достатній власний досвід культури спілкування і співпраці в різних видах навчальної діяльності.

Щодо формування СК у діалогічному мовленні в учнів 6-го класу, зауважимо, що в Навчальній програмі використано лише поняття «соціокультурна компетентність», а у змісті вимог до їі формування знаходимо такі завдання, як набуття знань культуро-специфічних правил і норм спілкування; знань ритуалів та стандартизованих моделей комунікативної та некомунікативної поведінки та вміння користуватися ними (Навчальні програми з іноземних мов для загальноосвітніх навчальних закладів і спеціалізованих шкіл із поглибленим вивченням іноземних мов 5 - 9 класи, 2017, с. 16-18).

Деталізуємо сфери та тематику ситуативного спілкування учнів 6-го класу закладів загальної середньої освіти (рис. 1):

Особистісна:
- Я, моя сім'я, мої
друзі
- Покупки
- Харчування

\section{Публічна:}

- Подорож

- Англомовні країни

Рис. 1 Сфери та тематика ситуативного спілкування учнів 6-го класу закладів середньої загальної освіти

Згідно з чинною програмою з іноземних мов для закладів загальної середньої освіти 2019-2020 р., Міністерство освіти і науки України виділяє очікувані соціальні відповідності учнів середньої школи (5-9 класи) на кінець навчального року, а саме:

1) учень виконує і реагує на основні мовленнєві функції, такі як запит, надання та обмін інформацією, а також вираження простими засобами своїх поглядів і ставлень;

2) спілкується просто, але ефективно, використовує загальновживані вирази та дотримується загальноприйнятих норм комунікативної поведінки;

3) усвідомлює і звертає увагу на найважливіші відмінності між звичаями, звичками, правилами поводження, цінностями та ідеалами, характерними для власної спільноти та країни виучуваної іноземної мови (Програма/рівень стандарту/для учнів 6-го класу середніх загальноосвітніх навчальних закладів, 2017, с. 22).

4) оволодіває типовими формулами мовленнєвого етикету, національно специфічними правилами і нормами спілкування та моделями поведінки, релевантної для їх вікової та соціальної групи.

у нашій роботі ми розглядаємо формування інтегрованих компетентностей, а саме: англомовної соціальної компетентності та компетентності в діалогічному мовленні (КДМ), що є методично доцільним та ефективним підходом до формування IKK. 
Тож розглянемо детальніше КДМ.

Проблемою розвитку і формування КДМ займалося багато вчених, серед яких Ю. Пасов, В. Скалкін, Т. Олійник, В. Черниш та інші.

КДМ - це здатність реалізовувати усномовленнєву комунікацію в діалогічній формі в життєво важливих для певного віку сферах і ситуаціях спілкування відповідно до комунікативного завдання. Вона передбачає, що мовець уміє планувати, здійснювати й коригувати власну комунікативну поведінку під час породження та варіювання іншомовного мовлення в різних типах діалогічних висловлювань відповідно до певної ситуації спілкування (контексту), мовленнєвого завдання і комунікативного наміру та згідно з правилами спілкування (Методика навчання іноземних мов і культур, 2013, с. 302).

В. Черниш стверджує, що діалогічне мовлення - це процес мовленнєвої взаємодії двох або більше учасників спілкування. У межах мовленнєвого акту кожен з учасників по черзі виступає як мовець (ініціатор спілкування - адресант) і як слухач (партнер по спілкуванню - адресат) (Черниш, 2012, с. 11).

Першим складником КДМ є мовленнєві, навчальні, інтелектуальні, організаційні та компенсаційні вміння.

До мовленнєвих умінь ДМ відносяться: ініціювати й закінчувати діалог; підтримувати спілкування; використовувати мовленнєві кліше, притаманні діалогам різних функціональних типів; розширювати запропоновану співрозмовником тему розмови, переходити на іншу тему; запитувати інформацію; комбінувати репліки; адекватно реагувати на репліки співрозмовника; емоційно забарвлювати діалог, використовуючи відповідну інтонацію, жести, міміку, вигуки, характерні для мовленнєвої поведінки носіїв мови (Черниш, 2012, с. 12).

На формування КДМ впливає рівень сформованості в учнів інтелектуальних умінь, наприклад, для ДМ велику роль відіграє ймовірне прогнозування, тобто вміння передбачити можливу фразу співрозмовника, уміння класифікувати, систематизувати і критично оцінювати отриману в процесі спілкування інформацію, уміння використовувати як фактичну інформацію, так і власну точку зору, власні коментарі з теми (Методика навчання іноземних мов і культур, 2013, с. 302).

Важливу роль також відіграють навчальні вміння, зокрема використання електронних засобів навчання, уміння використовувати опори різного характеру, та організаційні вміння, наприклад вміння передбачити та правильно сформувати свою мовленнєву діяльність, правильно вибрати зміст акту спілкування, уміння знайти адекватні засоби для передання змісту, уміння забезпечити зворотній зв'язок (Методика навчання іноземних мов і культур, 2013, с. 303). 
Компенсаційні вміння - уміння виходити зі складного положення в умовах дефіциту мовних засобів під час спілкування іноземною мовою. До таких умінь можна віднести вміння повернутися до раніше сказаного, уміння передати значення слова, яке учень не знає чи е може пригадати; уміння спрощення фраз; уміння застосовувати адекватні НЗК (Черниш, 2012, с. 11).

Ефективність розвитку вмінь ДМ зумовлюється рівнем сформованості у школярів мовних компетентностей. Таким чином, на формування i розвиток здібності учнів вести діалог впливає рівень сформованості мовленнєвих навичок (як рецептивних, так і репродуктивних), фонетичних (слухо-вимовних) навичок, лексичних навичок та граматичних навичок.

Фонетичні навички забезпечують сприймання й розпізнавання окремих звуків та їх сполучень у мовленнєвому потоці, а також різних інтонацій та оформлення власного висловлювання відповідно до фонетичних норм мови, що вивчається.

Лексичні навички забезпечують розпізнавання звукових образів до та їх безпосереднього розуміння, надають можливість вибирати й поєднувати ло згідно із замислом висловлювання.

Граматичні навички забезпечують розпізнавання на слух граматичних форм і прогнозування синтаксичних структур, уможливлюють правильно оформлювати своє висловлення відповідно до граматичної норми іноземної мови, що вивчається.

\section{Ще однією складовою КДМ є декларативні та процедурні знання.}

Декларативні знання: мовні та мовленнєві знання (фонеми, інтонеми; ЛО, мовні кліше; граматичні структури, функціональні типи діалогів та їх лінгвістичні особливості. До них також належать країнознавчі завдання: культура країни IM, що вивчається; значення паралінгвістичних явищ (жестів, міміки, проксеміки тощо).

До процедурних знань можна віднести соціокультурні знання, зокрема моленнєвої і не мовленнєвої поведінки носіїв IM у процесі спілкування, знання як планувати, організовувати, здійснювати й коригувати мовлення.

Отже, розглянемо очікувані інтеракційні відповідності учнів 6-го класу у формуванні компетентності в діалогічному мовленні на кінець навчального року:

1) учень спілкується досить легко в реальних та умовних комунікативних ситуаціях, якщо співрозмовник допоможе в разі необхідності;

2) веде прості повсякденні розмови без надмірних зусиль;

3) ставить запитання й відповідає на запитання, обмінюється думками та інформацією на близькі/знайомі теми в передбачуваних повсякденних ситуаціях;

4) розуміє достатньо, щоб задовольнити конкретні потреби, якщо мовлення чітке й повільне (Програма/рівень стандарту/для учнів 6-го класу середніх загальноосвітніх навчальних закладів, 2017, с. 22); 
5) спілкується, дотримуючись основних норм, прийнятих у країнах, мова яких вивчається;

6) адекватно поводитися в комунікативних ситуаціях, демонструючи мовленнєву поведінку, характерну для носіїв мови;

7) використовує міміку і жести.

Узагальнимо вимоги до формування англомовної соціальної компетентності інтегровано з навчанням діалогічного мовлення учнів 6-го класу (табл. 2).

таблиця 2

\section{Очікувані результати успішності учнів 6-го класу згідно з Навчальною програмою}

\begin{tabular}{c|c|}
\hline Соціальна компетентність & компетентність у діалогічному мовленні \\
\hline Очікувані результати
\end{tabular}

\begin{tabular}{ll|l}
\hline Учень виконує і реагує на основні & Учень спілкується досить легко в реальних \\
мовленнєві дії, такі як запит, надання та & та умовних комунікативних ситуаціях, \\
обмін інформацією, а також вираження & $\begin{array}{l}\text { якщо співрозмовник допоможе у разі } \\
\text { простими засобами своїх поглядів і } \\
\text { ставлень }\end{array}$ & \\
\hline $\begin{array}{l}\text { Спілкується просто, але ефективно, використовуючи загальновживані вирази та } \\
\text { дотримуючись загальноприйнятих норм комунікативної поведінки }\end{array}$
\end{tabular}

Усвідомлює і звертає увагу на найважливіші відмінності між звичаями, звичками, правилами поводження, цінностями й ідеалами, характерними для власної спільноти та країни, іноземна мова якої вивчається

\begin{tabular}{llr|lrr} 
Оволодіває типовими & формулами & Ставить запитання й відповідає на \\
мовленнєвого & етикету, & національно & запитання, обмінюється думками та \\
специфічними правилами й нормами & інформацією на близькі/знайомі теми в \\
спілкування і моделями поведінки, & передбачуваних повсякденних ситуаціях, \\
релевантної для їх вікової та соціальної \\
групи
\end{tabular}

Спілкується, дотримуючись основних норм, прийнятих у країнах, мова якої вивчається (у нашому випадку англійська)

Адекватно поводиться в комунікативних ситуаціях, демонструючи мовленнєву поведінку, характерну для носіїв мови

Розуміє достатньо, щоб задовольнити конкретні потреби - мовлення чітке й повільне

Використовує НЗК

Для виявлення сучасного стану формування в учнів 6-х класів закладів загальної середньої освіти СК інтегровано з КДМ у межах даної роботи ми провели опитування серед 60 учнів 6-х класів, які вивчають англійську як першу іноземну в таких закладах середньої освіти, як Тернівська загальноосвітня школа I-III ступенів, Комунальна установа Сумська класична гімназія та Комунальна установа Сумська гімназія № 1.

У ході аналізу результатів даного опитування ми з'ясували, що $40 \%$ учнів не обговорюють інтонацію головних героїв діалогу-зразку, 33 \% звертають на це увагу, та 27 \% обговорюють головних героїв запису, але не 
виокремлюють їх інтонацію. $57 \%$ опитувальних майже ніколи не розігрували діалоги як актори, 20 \% взагалі ніколи цього не робили і лише 23 \% мали змогу побути акторами.

Опитування показало, що майже половина (47\%) учнів ніколи не використовувала міміку та жести під час розігрування діалогів, і лише 8 \% роблять це щоразу, решта учнів лише інколи використовують НЗК.

Щодо правил і норм спілкування англійців, то $55 \%$ учнів обговорювали їх на заняттях із іноземної мови, і $45 \%$ не мають про це й гадки. Також ми з'ясували, що для заохочення учнів навчатися англійській мові необхідно запровадити розігрування діалогів із відомих англомовних фільмів, адже для 77 \% опитуваних це здалося гарною ідеєю.

Для об'єктивної оцінки сучасного стану проблеми формування СК інтегровано з КДМ в учнів 6-го класу нами було проаналізовано низку посібників з англійської мови, що пропонуються Навчальною Програмою.

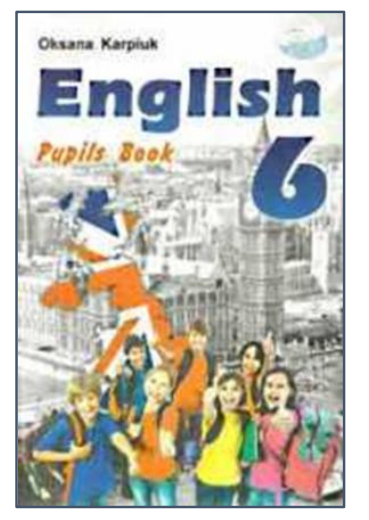

Щодо підручника Shops".

У ході аналізу підручника О. Карп'юк (Карп'юк, 2014) було з'ясовано, що на формування КДМ виділено $18 \%$ підручника, що задовольняє потреби навчальної Програми, тоді як завдання, що стосуються формування СК складають лише 3,7 \% від загального обсягу підручника. Для формування інтегрованих КДМ та СК відводиться лише 1,3 \% під час вивчення теми "Cafes and

виявилося, що завдання, що стосуються формування КДМ займають 25,6 \% посібника, що вказує на велику перевагу підручника, адже розроблені вправи сприяють розвиткові в учнів усного діалогічного мовлення. Проте, формуванню СК відводиться лише 2,8 \% від загального обсягу підручника.

Таким чином, аналіз існуючих посібників надає можливість стверджувати про нагальну потребу відбору

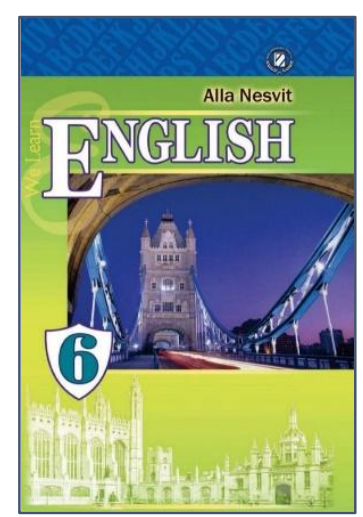
або розроблення нових підручників, які $б$ ураховували всі необхідні вимоги до посібників такого типу та містили необхідні вправи та завдання для інтегрованого формування всіх компонентів IKK, зокрема для формування компетентності в діалогічному мовленні та соціальної компетентності, що $€$ методично виправданим та ефективним.

Подальшу перспективу дослідження вбачаємо в розробленні комплексу вправ та завдань для формування в учнів 6-го класу закладів загальної середньої освіти англомовної соціальної компетентності у процесі навчання діалогічного мовлення. 


\section{ЛІТЕРАТУРА}

Азимов, Э. Г., Щукин, А. Н. (2009). Новый словарь методических терминов и понятий (теория и практика обучения языкам). М.: Изд-во ИкАР (Azimov, E. G., Shchukin, A. N. (2009). New dictionary of methodological terms and notions (theory and practice of teaching languages). M: IKAR).

Бігич, О. Б., Бориско, Н. Ф., Борецька, Г. Е. (2013). Методика навчання іноземних мов і культур: теорія і практика, С. Ю. Ніколаєва (ред.). Київ: Ленвіт (Bigych, О. В., Borysko, N. F., Boretska, G. E. (2013). Methods of Teaching Foreign Languages and Cultures: Theories and Practice, S. Yu. Nikolaeva (Ed.). Kyiv: Lenvit).

Дука, М.. (2015). Методика фрормування у майбутніх фрілологів лінгвосоціокультурної компетентності у процесі читання англомовних художніх творів (дис. ... канд. пед. наук: 13.00.02). Київ (Duka, M. V. (2015). The Methodology of Developing Linguosociocultural Competence of Future Philologists while Reading English Fiction (PhD thesis). Kyiv).

Загальноєвропейські Рекомендації з мовної освіти: вивчення, викладання, оцінювання (2003), С. Ю. Ніколаєва (ред.). Київ: Ленвіт (European Recommendations on Language Education: Learning, Teaching and Evaluation (2003), S. Yu. Nikolaeva (Ed.). Kyiv: Lenvit).

Карп'юк, О.Д. (2014). Англійська мова. Підручник для 6-го класу загальноосвітніх навчальних закладів (6-й рік навчання). Тернопіль: «Видавництво Астон». (Karpiuk, O. D. (2014). English. Pupil's Book 6 ( $6^{\text {th }}$ Year of Studying). Ternopil: "Publishing house Aston").

Колтунова, М. В. (2005). Конвенции как прагматический фрактор делового диалогического общения. М.: Акад. гуманитар. исслед (Koltunova, М. V. (2005). Conventions as the pragmatic factor of business dialogue communication. Moscow: Academ. humanitarian studies).

Навчальні програми з іноземних мов для загальноосвітніх навчальних закладів $і$ спеціалізованих шкіл із поглибленим вивченням іноземних мов 5 -9 класи (Programs on teaching foreign languages at general institutions and schools with profound studies of foreign languages in 5-9 classes) (2017). Retrieved from: https://mon.gov.ua/storage/app/media/zagalna\%20serednya/programy-5-9klas/programi-inozemni-movi-5-9-12.06.2017.pdf).

Несвіт, А. М. Англійська мова. Підручник для 6-го класу загальноосвітніх навчальних закладів (6-й рік навчання). Київ: «Видавництво Генеза» (Nesvit, А. М. (2014). English. Pupil's Book 6 ( $6^{\text {th }}$ Year of Studying). Kyiv: "Publishing house Geneza").

Панова, Л. С., Андрійко, І. Ф., Тезікова, С. В. (2010). Методика навчання іноземних мов у загальноосвітніх навчальних закладах. Київ: «Академія» (Panova, L. S., Andriiko, I. F., Tezikova, S. V. (2010). Methods of Teaching Foreign Languages at General Education Institutions. Kyiv: "Academia").

Програма /рівень стандарту/ для учнів 6-го класу середніх загальноосвітніх навчальних закладів (2017). Київ (Program / standard level/for pupils of the $6^{\text {th }}$ form secondary institutions (2017). Kyiv).

Тер-Минасова, С. Г. (2008). Война и мир языков и культур. Москва: Слово/Slovo (TerM inasova, S. G. (2008). War and Peace of Languages and Cultures. Moscow: Slovo).

Тульнова, М. А. (2010). Табу в контексте глобализации. Политическая лингвистика, 4 (34), 176-180 (Tulnova, M. A. (2010). Taboos in the Context of Globalization. Political Linguistics, 4 (34), 176-180).

Черниш, В. В. (2012). Навчання іншомовного діалогічного мовлення в аспекті компетентнісного підходу. Іноземні мови, 4, 11-27 (Chernysh, V. V. (2012). 
Teaching Foreign Spoken Interaction in the Aspect of the Competency Based Approach. Foreign Languages, 4, 11-27).

Wardhaugh, R. (2006). An Introduction to Sociolinguistics (Fifth edition). Oxford: Blackwell

Publishers Ltd.

\section{PEЗЮME}

Дука Мария, Холодная Маргарита. Требования к формированию англоязычной социальной компетентности в процессе обучения диалогической речи учеников 6-го класса учреждений среднего общего образования.

В статье освещен ряд теоретических положений относительно формирования англоязычной сочиальной компетентности в процессе обучения диалогической речи учащихся 6-го класса учреждений общего среднего образования. Систематизированы подходы к определению понятия «англоязычная социальная компетентность». Проанализированы требования $\kappa$ формированию англоязычной социальной компетентности в прочессе обучения диалогической речи, представленные в действующей школьной программе $\mathrm{MOH}$ для учащихся 6-го класса учреждений общего среднего образования и выяснено, что для лучшего овладения учащимися социальной компетентностью в процессе обучения диалогической речи следует обратить внимание на требования к обучению этих интегрированных компетенций в средних классах, которые определены в государственной программе, а также учебные пособия, по которым учатся школьники. Доказана методическая целесообразность и эффрективность формирования у учащихся 6-го класса интегрированной социальной компетентности и компетентности в диалогической речи.

Ключевые слова: диалогическая речь, сочиальная компетентность, лингвосоциокультурная компетентность, учреждение общего среднего образования, невербальные средства коммуникации.

\section{SUMMARY}

Duka Maria, Kholodna Marharyta The Particularities of English Social Competence Formation in the Process of Teaching Dialogic Speech in the $6^{\text {th }}$ form.

The article overviews the theoretical prerequisites as for the organization of the process of forming social competence of the $6^{\text {th }}$ form pupils in secondary education institutions in the process of learning dialogic speech. The approaches to defining the notion "social competence" were singled out and the special components of the competence mentioned were analyzed, among which there are the knowledge of verbal and non-verbal communication, language etiquette, taboo, rituals, traditions and customs and the skills to use. The necessity of teaching understanding non-verbal signals in the process of forming of linguo-sociocultural competence is proved. Non-verbal signals are defined as the meaningful movements of a person, including gestures, mimics, pantomimics, changes of personal space, distance, particularities of voice and the specific static details as clothing, style of hairdo, accessories, jewelry, tattoos etc. It is proved that bearing implicit great meaning, those nonverbal signals mentioned should be taken into consideration. The whole number of nonverbal symbols as the non-verbal behavior of a person express psychological states of a person, his/her attitude to the partner and to the situation in which the conversation takes place in general.

The components of the dialogic speech competence were studied. The requirements concerning forming social competence of the $6^{\text {th }}$ form pupils in secondary education institutions in the process of learning dialogic speech were generalized. According to the research conducted, the problem of forming linguosociocultural competence is stated in general, when the specific tasks, which concern non-verbal signals in the process of communication, taboos, etiquette are not specified. 
Thus, the article is aimed at observing the problem of integral forming social competence of the $6^{\text {th }}$ form pupils in secondary education institutions in the process of learning dialogic speech.

Key words dialogic speech, social competence, linguosociocultural competence, general secondary education institution, non-verbal means of communication.

удк 796.071.4:[37.018.54:796]-053.6:316.422(477.52)

Олександр Міщенко

Сумський державний педагогічний університет імені А.С. Макаренка ORCID ID 0000-0002-1157-198X

Віталій Лапицький

Сумський державний педагогічний університет імені А.С. Макаренка ORCID ID 0000-0002-4867-6857

Анатолій Ратов

Сумський державний педагогічний університет імені А.С. Макаренка ORCID ID 0000-0001-6968-1543

Євген Солоненко

Сумський державний педагогічний університет імені А.С. Макаренка ORCID ID 0000-0003-4715-1028 DOI 10.24139/2312-5993/2020.02/361-373

\section{СТАВЛЕННЯ ТРЕНЕРІВ ДЮСШ СУМСЬКОЇ ОБЛАСТІ ДО РЕФОРМУВАННЯ СПОРТИВНОЇ СФЕРИ}

У статті представлено результати опитування слухачів курсів підвищення кваліфікації тренерів ДЮСШ та спортивних клубів, організованих на базі кафедри ТМС ННІФК СумДПУ імені А. С. Макаренка. Аналіз проведеного дослідження вказує на думку тренерів щодо напрямів подолання тієї негативної ситуації у сфрері фізичної культури і спорту, яка є наразі в Сумській області. Серед зазначених слід виділити утримання ДЮСШ за рахунок державних коштів, побудову сучасних спортивних споруд, закупівля нового інвентарю та обладнання, збільшення заробітної плати тренерам, виділення грошової компенсації тренерам за перебування у відрядженні з командою юних спортсменів.

Ключові слова: нормативно-правова база, спортивні школи, тренер, фрінансування спорту, матеріально-технічне забезпечення, позабюджетні кошти.

Постановка проблеми. Забезпечення здоров'я населення $є$ одним із головних завдань держави, особливо це стосується підростаючого покоління. Одним із напрямків формування здорового способу життя дітей $\epsilon$ залучення їх до занять у спеціалізованих спортивних закладах, бо саме дитячо-юнацькі спортивні школи, як вказано у «Положенні про дитячоюнацькі спортивні школи» (2016), створює необхідні умови для гармонійного виховання, фізичного розвитку, повноцінного оздоровлення, змістовного відпочинку і дозвілля дітей та молоді, самореалізації, набуття навичок здорового способу життя, підготовки спортсменів для резервного спорту (Положення про дитячо-юнацьку спортивну школу, 2016). 